\title{
2016 年度博士論文抄録への原稿提出のお願い
}

博士論文の要旨（和文）を地理学評論（7月号）に掲載します。2016 年度に博士号を取得した方は,「氏名， 論文名, 学位取得大学, 取得年月, 和文要旨 (800 字以内)」を記載したハードコピー 1 部と電子ファイルを下 記まで，3月24日(金) までに提出のほど抒願いいたします.

送付先 テ 113-0032 東京都文京区弥生 2-4-16 学会センタービル内 公益社団法人日本地理学会 地理学評論編集専門委員会 e-mail: office@ajg.or.jp

\section{会費種別の変更手続きについて}

年会費は当該年度の 4 月 1 日現在の所属に基づきます. 2016 年 4 月 1 日に大学・大学院等に在学している学 生, 研究生またはそれに準ずる会員で, 学生会費納入者として認定された会員の年会費は 7,000 円（学生会費） となっています。卒業・修了・退学等により 2017 年 4 月 1 日以降に学生会費納入資格を失う見込みが確実に なった方は, 正会員（年会費は 12,000 円）への会員種別変更の手続きが必要です。まだ種別変更手続きをして いない会員は, 2017 年 3 月末日までに必ず変更手続きを行ってください，変更については，本会ホームページ URL http://www.ajg.or.jp/ 日本語トップページの「入会のご案内」より, 日本地理学会入会申込書をダウン ロードし，八ガキ大にプリントアウトして所定の事項を記入し，あわせて備考闌に必ず，「学＼cjkstart正」と朱書きの 上，学会事務局まで抒送り下さい，また，正会員会費納入者から学生会費納入者への変更の場合は「正 $\rightarrow$ 学」 と朱書きの上，3月9日（木）までに学会事務局までお送り下さい.

\section{「会費自動引落し方式」への協力のお願い}

日本地理学会では, 郵便局と身近な金融機関（都市銀行・地方銀行・信金・信組・労金等）を利用した会費 自動引落し方式を実施しています．2017年1月末現在，海外会員を除くと，約半数の会員が利用されています． 「自動引落し方式」は学会事務の軽減・収入の安定などにつながるため, 御利用いただきますようお願い申し上 げます。

なお，申込みの方法につきましては学会事務局へお問い合わせ下さい.

問合せ先：日本地理学会事務局

電話 03-3815-1912

FAX 03-3815-1672

\section{自動引落しの通帳記載について}

会費等を各会員の口座より自動引落しさせていただきますと, 通帳に「チリガッカイヒ」または「セデイナ」 と記載されます。「セディナ」は本会が学会費等の自動引落し業務を委託している会社です。自動引落しされ た会費等は「セディナ」を通して三井住友銀行の本会口座へ入金されるシステムになって扔ります。通帳の御 確認を扔願いいたします。

\section{NHK 番組アーカイブス学術利用トライアル 2017 年度第 2 回募集}

1. 締切 3 月 24 日 (金)。2. 詳細 URL http://www.nhk.or.jp/archives/academic/

\section{公益財団法人国土地理協会学術研究助成}

1. 申請期間 4 月 3 日（月） 21 日（金）必着. 2. 詳細 URL http://www.kokudo.or.jp/grant/index.html 


\author{
Geographical review of Japan Series B Vol. 89, No. 1 (2016) の目次
}

Preface to the Special Issue on "Rethinking Gender and Geography in Japanese Contexts" KUMAGAI K. and YOSHIDA Y: Preface to the Special Issue "Rethinking Gender and Geography in Japanese Contexts" $\cdot 1-3$

Review Article of the Special Issue on "Rethinking Gender and Geography in Japanese Contexts" YOSHIDA Y: Geography of Gender and Qualitative Methods in Japan: Focusing on Studies that have Analyzed Life Histories $\cdot 4-13$

Article of the Special Issue on "Rethinking Gender and Geography in Japanese Contexts" KURAMITSU M: Samoan Pioneer Wives and 'Home': From the Experiences of Living in Japan more than 20 years $\cdot 14-25$

Research Note of the Special Issue on "Rethinking Gender and Geography in Japanese Contexts" KAGEyAmA H.: Community Building in Naha Shintoshin, Okinawa from the View of Gender Studies • $26-31$

Article of the Special Issue on "Rethinking Gender and Geography in Japanese Contexts" KUMAGAI K: Place, Body and Nature: Rethinking Japanese Sense of Fudo and Minamata Disease $\cdot 32-45$

詳しくは下記サイトを参照下さい

https://www.jstage.jst.go.jp/browse/geogrevjapanb 


\section{公益社団法人日本地理学会入会の御案内}

日本地理学会は 1925 （大正 14）年に創立された日本の地理学界を代表する学会です. 現在の会 員は, 大学・研究所・企業等の研究者・技術者や小・中・高校の教員を中心に, その数は約 3,000 人に達しています。会員の研究分野は地形・気候・水文・植生・環境などの自然地理学，経済・ 社会・政治・人口・都市などの人文地理学のほか, 世界各地の自然・歴史・産業・文化などの総 合的な地域研究, 地図・GIS (地理情報システム)・リモートセンシングなど, 広い範囲にわたって います.

日本地理学会は, 近年のグローバルな環境危機や地震・火山噴火・地すべり・豪雨などの自然 災害に対して, 大地とそこに生活する人類を総合的に研究調査し, 具体的な対策の立案に大きく貢 献しています。また，国際化と国際理解の推進，国土の開発と保全，社会の持続的発展の可能性の 追求，空間的情報処理技術の開発など多くの今日的な課題に取り組んでいます。さらに，これらの 学術的成果を次の世代に伝えるために, 地理学や地域情報の教育実践・普及についても活発な活 動を行っています。

1. 日本地理学会の活動：1）地理学に関する研究・調査およびその奨励，2）機関誌の発行（機 関誌「地理学評論, Geographical Review of Japan Series B, E-journal GEO」), 3）年 2 回（春 · 秋）の学術大会, その他の研究集会, 講演会, 現地見学会などの開催, 4) 国内および海外の学術 諸団体その他の機関との連絡・交流.

2. 会員の種類：正会員は, 地理学に関心をもち, 本会の目的に賛同し年会費（12,000 円; 学生 会費納入者は 7,000 円）を納める個人。機関誌の定期購読, 研究発表, 各種集会への参加, 本会施 設の利用などができるほか, 各種役員の選挙権・被選挙権を有する。このほかに「名誉会員」「「賛 助会員」があります，詳しくは学会事務局までお問い合わせ下さい.

3. 入会の方法: 本会ホームページ URL http://www.ajg.or.jp/日本語トップページの「入会の ご案内」より日本地理学会入会申込書をダウンロードし, ハガキ大にプリントアウトして必要事項 を御記入の上，封書で日本地理学会まで扮送り下さい，入会申込書は郵送することもできますの で, 必要な場合は学会事務局までお申し出下さい。後日, 会費納入方法などについて御連絡いたし ます。 